\title{
Adapting or Freezing? Ideological Reactions of Communist Regimes to a Post-Communist World
}

\author{
Alexander Dukalskis $^{1 *}$ and Johannes Gerschewski ${ }^{2}$ \\ ${ }^{1}$ Alexander Dukalskis, School of Politics \& International Relations, University College Dublin, Dublin, \\ Ireland and ${ }^{2}$ Johannes Gerschewski, Faculty of Humanities and Social Sciences, Humboldt-University, \\ Berlin, Germany \\ ${ }^{*}$ Corresponding author. Email: alexander.dukalskis@ucd.ie
}

(Received 19 April 2018; revised 8 August 2018; accepted 17 September 2018; first published online 27 November 2018)

\begin{abstract}
This article studies the ideological reactions of communist regimes to the advent of a postcommunist world. It examines two cases of reformed communist regimes (China and Vietnam) with two relatively unreformed cases (North Korea and Cuba) to understand different legitimation strategies employed during and after the downfall of the Soviet Union. Theoretically, the article compares two ideal-type approaches to ideology in autocratic regimes. The first approach emphasizes semantic 'freezing' over time. The consistency and coherence of ideology is underlined. The second approach argues that the success of an ideology lies in its ability to be a dynamic, adaptive force that can react with changing circumstances. Four parameters help to distinguish the freeze-frame end from the adaptation pole: (1) the autonomy over semantic changes, (2) the timing, (3) the velocity and (4) the distance that an ideology moves. Using qualitative case-based analysis that is enriched with quantitative text analysis of communist party documents, this article compares these contending conceptions of ideology with each other in the four cases. Sharing similar starting conditions in the 1970s, the article shows how China and Vietnam harnessed a flexible legitimation strategy while North Korea and Cuba adopted a comparatively rigid legitimation approach.
\end{abstract}

Keywords: authoritarianism; communism; legitimation; ideology; China; North Korea; Cuba; Vietnam

Communism has become an unusual but resilient form of autocratic rule. While constituting a major ideological orientation for most of the 20th century (McAdams 2017), contemporary forms of autocratic rule have shifted their legitimation patterns away from communism. The modal form of authoritarianism in the post-Cold War world may indeed be some version of electoral authoritarianism (Levitsky and Way 2010; Schedler 2013). However, the remaining communist regimes have shown remarkable endurance. Taken together, these governments have an average lifespan of more than 50 years as of 2018 . 
A recent effort to understand the non-collapse of the remaining communist regimes identifies four domains that bear on their resilience: economic reforms, measures to co-opt beneficiaries, institutional innovations and ideology (Dimitrov 2013). This article focuses only on the last dimension of Martin Dimitrov's fourfold framework: ideology. It provides a comprehensive account of two distinct pathways taken by surviving communist regimes to legitimate their rule in a post-communist world. In so doing, the article makes a wider contribution to the study of political ideologies and autocratic legitimation by proposing a spectrum to conceptualize and assess the relative adaptability of legitimating ideologies to changing circumstances.

To be explicit at the very beginning, the article attempts to understand in structured comparative detail how the legitimation of communist parties in China, Vietnam, Cuba and North Korea adapted to the ostensible end of global communism. ${ }^{1}$ Given that we study only successful cases, the article is not able to engage in a covariational analysis that would allow for causal reasoning about determinants of regime survival. Instead, we strongly advocate the merits of studying the procedural 'how' question intensively and examining the differing pathways these regimes took.

In this light, the article proposes a theoretical template to distinguish between two major ideological reactions: freeze-frame and adaptation. While the former captures a strategy of immobilizing semantic changes and fixing ideological meaning despite changing circumstances, the latter engages proactively with a changing environment and adjusts ideological meaning. We introduce four parameters that help to distinguish empirically these two basic strategies: (1) autonomy over semantic changes, (2) timing, (3) velocity and (4) ideological distance.

We demonstrate that the autocratic party-states in China and Vietnam on the one hand, and North Korea and Cuba on the other, took different approaches to legitimizing their rule from the 1980s onwards. While all four regimes shared similar starting conditions in the 1970s, China and Vietnam, amid major reforms in economic and foreign policy, attempted to legitimate their rule with an adaptive and dynamic approach to ideology that sought to change alongside non-ideological developments. Cuba and North Korea took a more rigid approach to legitimation as the world tilted away from communism and sought instead to retain their ideologies with less compromise. The ideological adaptations that Pyongyang and Havana did make during the 1990s were eleventh-hour efforts at regime survival rather than proactively adaptive. In this sense they were forced capitulations undertaken from a position of relative weakness while the more pre-emptive and thoroughgoing adaptations made by China and Vietnam were made by choice as a strategy to strengthen the foundation for communist party survival in a changing world. Relatively early experimentations by China and Vietnam with ideological flexibility made it easier to adapt to changes in the broader communist world in the late 1980s and early 1990s. The more reactive attempts by North Korea and Cuba during the 1990s occurred late and made it difficult for each state to introduce flexibility without undermining its ability to legitimate party rule.

To substantiate these arguments, this article uses three types of evidence. First, it engages in structured qualitative case-based analysis of relevant political developments in the late 1980s and early 1990s in each country. Second, it draws on 
qualitative analysis of primary documents and speeches from the government of each state. Third, it advances arguments using quantitative text analysis of government documents from one case representing each of the hypothesized legitimation strategies: China and North Korea. The methods will be described in more detail but by way of preview the effort involved both frequency analysis (amount of word usage) and keyword-in-context analysis (how terms relate to one another) to illuminate the legitimation patterns of each regime.

This article proceeds in four sections. First, a discussion of different conceptions of legitimation and its role in autocratic resilience will establish the theoretical relevance of the article. Second, the methodological procedure will be described, including the process for deriving terms for analysis and selecting texts. Third, the empirical analysis will be presented in two subsections. An empirical examination of the efforts by North Korea and Cuba will reveal on the one hand a comparatively rigid approach to ideological legitimation while the analysis of China and Vietnam highlights a comparatively adaptable approach to the role of ideology and legitimation in sustaining communist party rule. Fourth, the article concludes with remarks about the wider relevance of this research.

\section{Approaches to ideology and legitimation in contemporary autocracies}

It is difficult for leaders to justify ruling a modern state without at least a perfunctory acknowledgement of public participation (see Dahl 1971: 5). This reality often leads autocratic leaders to justify their rule based on grounds of performance or temporary expediency or to construct 'competitive authoritarian' electoral systems in which they attempt to manipulate the institutions of democracy to remain in power (Levitsky and Way 2010; Schedler 2013). Yet some modern autocratic regimes do not base their legitimacy entirely on performance or on participation and instead construct and propagate ideologies that help explain why they are entitled to rule and what they intend to do with their power (Barker 2001; Beetham 1991; Gilley 2009).

Legitimation is understood as one of the crucial pillars of autocratic resilience (Gerschewski 2013). Autocracies censor the public sphere to shield their legitimation messages from public challenge and ultimately to quash the potential for anti-regime collective action (Dukalskis 2017; King et al. 2013). Of course, if citizens of autocratic states express support for the dominant ideology, it is difficult to know if this loyalty is feigned in order to avoid repression, a genuinely held belief, or something in between (Chwe 1999; Kuran 1997). To answer the question to what extent the autocratic regime has been successful in promoting a belief in its legitimacy among its citizens is beyond the scope of this article. However, we take the legitimacy claim of the regime seriously. We maintain that it is important to study what autocracies actually say about why they are entitled to rule (Dukalskis and Gerschewski 2017; Gerschewski 2018). If we set aside the question of belief, the result of an autocratic government promoting its ideology and censoring deviations can be to winnow public discourse to such narrow bounds that mustering arguments and information to oppose the government becomes more difficult (Kuran 1997). Furthermore, the ability of an autocratic regime to compel people to perform in public as if they believe in its dominant narratives and symbols 
simultaneously demonstrates and reifies the regime's power, thereby discouraging collective challenges (Wedeen 1999).

A difficulty of studying legitimation is the definitional ambiguity that surrounds most key terms necessary to proceed with analysis (Gill 2011). Conceptual essays on ideology, for example, frequently note that the term's definition is contested (Gerring 1997; Maynard and Mildenberger 2018). While the dominant approach in political research is to treat ideology as a relatively coherent set of political ideas that can be measured along the familiar left-right spectrum (Knight 2006), this strategy is of limited utility in helping to explain how and with what effect autocracies deploy ideas, narratives and symbols into a censored and policed public sphere. By assigning overly strict standards of coherence to ideologies and those motivated by them, one runs the risk of defining ideology so narrowly that one is bound to find that its impact is marginal (Jost 2006).

Ideology is often used as a legitimating device, but the question of the extent to which a legitimating ideology needs to remain coherent and stable is still an open question. To what degree do autocratic leaders attempt to fix (or at least stabilize) the meanings of their legitimation efforts in order to achieve consistency in their messages? Alternatively, how much adaptability do autocratic leaders allow their legitimation messages to display in order to keep pace with changing realities - and does the adaptation encompass all spheres of an ideology or is it restricted to peripheral areas?

To address these theoretical questions in the context of communist autocracies, this article conceives of legitimation strategies as a continuous spectrum. On one end is an effort to 'freeze' the meaning of legitimating ideologies while on the other end is a contrasting strategy that sees the content and meaning of legitimating ideologies adapted to changing circumstances. Both strategies share the singular aim of keeping the government in power.

The first ideal type is the freeze-frame strategy. This term is borrowed from Michael Freeden's ideological analysis. He argues that all political ideologies share a common morphology of different layers. They have a core and more adjacent elements. $^{2}$ They form a 'macroscopic structural arrangement that attributes meaning to a range of mutually defining political concepts' (Freeden 1994: 141). In this sense, an ideology is an assemblage of concepts that are held together. The crux, however, is that these concepts are most often - in line with Walter Bryce Gallie (1956) - 'essentially contested'. Concepts such as freedom, equality and justice do not have consensual and clear-cut meanings. Instead, the semantics are manifold and shifting such that they are subject to constant negotiation and struggle. Different parties are aware of this 'contestedness' and use these concepts in a struggle to settle their meanings.

Freeden argues that the key aim of political ideologies is to make contested concepts decontested. 'Ultimately, ideologies are configurations of decontested meanings of political concepts' (Freeden 1996: 76). Ideologies therefore strive to limit semantic variety by stabilizing the meaning of a term in time and space and reducing any insecurity and rivalry about its proper usage. The term serves as a 'freeze-frame of the meanings of the concepts employed' (Freeden 1994: 158). An ideology assigns clear and unchanging meaning to its constituent concepts. Concepts are no longer free-floating units that could connect to various neighbouring 
concepts, but instead become rigid and pressed into a 'thought skeleton' in which the semantics are limited. They therefore aim to marginalize alternative interpretations of concepts and privilege their own perspectives.

If an ideology is able to impose a fixed and uncontested meaning on its audience that is unchanging over time, it can acquire a taken-for-granted quality and become a routinized script for everyday behaviour. In his classic work on the legitimation of power, David Beetham (1991: 65) argued that the creation of 'settled expectations' is one prerequisite for legitimate rule. If legitimacy claims can 'ensure predictability', they can produce a following. Only if people can rely on the validity and the intactness of these claims can they see them as legitimate. Overly frequent changes of basic claims, in contrast, can undermine the belief of the people in the legitimacy of the entitlement claims of the rulers. Against this backdrop, decontesting otherwise contested concepts and freezing their semantics is one route to legitimizing autocratic rule.

The second ideal type of legitimation that this article suggests is a strategy of flexible adaptation. In this view, an ideology is seen as a tool that adapts to a changing environment. If core or adjacent concepts that constitute the ideology, their relation to each other, or their semantic content changes, then an ideology reacts and adapts flexibly (Freeden 1996). Instead of ideological rigidity, adaptation is central.

In his classic functionalist studies, Talcott Parsons (1969) reminded us to see adaptation as one of the core functions that any social system needs to fulfil. A society needs to 'upgrade' its adaptive capacity. Karl Deutsch (1973: 145-149, 234) connects the idea of adaptability systematically with the notion of learning capacities. Adaptation contains for him the idea of a direct and unmediated feedback loop for a certain behaviour. An organization or regime is able to react to a new and iterating stimulus from outside. By doing so, an inner status is aimed for that reduces inner disequilibria.

Against this backdrop, Gabriel Almond and G. Bingham Powell stressed the important issues of capacity and agency. Adaptation is about 'political systems that "do something" about threats and challenges' (Almond and Powell 1978: 399). In this light, we see adaptation not only as a reactive phenomenon, but also as a proactive steering capacity of systems that demand autonomous room to manoeuvre. Proactive adaptation is important as it allows more procedural control.

Besides this autonomy, we introduce three additional parameters that provide useful criteria to assess the adaptation process. We borrow from Deutsch's work the idea of a second-order measurement of adaptation: the velocity by which a regime learns to learn. It refers to the question of how fast a regime is able to improve its performance when being confronted with challenges (Deutsch 1973: 240).

Furthermore, we assume that timing and distance matter. Distance refers in this context to how conceptually far an ideology travels from its original meaning to adapt to changing environments. How extensive and wide-ranging have the ideological changes been? Timing, in turn, accounts for when the adaptations actually occur in the political development of a country. Often, the question of timing is closely related to the question of autonomy. If the timing of semantic changes is too late, it usually results in a loss of autonomy. Late-movers that have 
missed the optimal point for adaptation are left only with a defensive and reactive strategy.

In sum, we distinguish between two poles of legitimation strategies. One strategy is guided by the attempt to freeze potentially changing semantics and render contested concepts decontested. Stable expectations are created that 'sink into' people's hearts and minds. The other pole refers to an adaptive strategy in which the regime adjusts its legitimacy formula to changing circumstances. Four parameters help understand the movement from the freeze-frame end of the spectrum to the adaptation pole: (1) the autonomy over the process, (2) the timing, (3) the velocity and (4) the distance that an ideology moves.

\section{Shared ideological morphology: nationalized variants of communism}

While the freeze-frame idea is a passive and (in the literal sense) conservative strategy, the adaptation strategy is active and reformist. The world's remaining communist regimes provide fruitful empirical material to illustrate these different strategies of legitimation. The following analysis assumes that each regime in question wished to remain in power. While Dimitrov (2013) has highlighted other important factors for communist resilience (see also Saxonberg 2013), the focus here is only on demonstrating the different pathways that regimes attempted to take in legitimating their rule. We do not aim to provide a causal argument based on covariation but take a procedural perspective in order to understand these pathways.

As the cases shared similar starting conditions, they are apt for demonstrating the diverging paths that they took subsequently. All of the parties in question, the Chinese and Vietnamese on the one hand and the Cuban and North Korean on the other, were created in a similar period of time and shaped during the Cold War period. They shared similar political and social conditions in the 1970s, the starting date of our analysis. However, during and after the collapse of Soviet communism in the late 1980s and early 1990s and the ostensible victory of liberal democracy and capitalism, the world's communist regimes faced choices about how to legitimate their rule. They could hold firm and maintain that they were the last bastions of national communism in an increasingly dangerous world or, alternatively, they could adapt and base their legitimacy on some modified conceptual constellation. These approximate the ideal types of freeze-framing ideological meaning and adapting ideological concepts to legitimate autocratic rule.

These regimes share a common ideological morphology: a nationalized variant of communism. The core of the regime legitimizing formula in all four countries has been a form of nationalism-cum-communism. From the beginning, all of the respective country leaders emphasized a national Sonderweg, a creative application of the communist orthodoxy to national circumstances. Indeed, this was a more general phenomenon within the communist world and proved to be a crucial element in the sustainability of virtually all independent communist regimes (McAdams 2017). The ideology was a mixture of both a national delineation from communism and a heavy reliance on its dogmas. The ideological core of all four countries is therefore a blend between the key concepts of 'nation' and 'communism' with the task of legitimating the entitlement claims of the ruling 
communist party. The party is propagated as the vanguard and due to its exceptional foresight, it is the legitimate force that should lead the people. What changes over time, however, is the respective weight that is given to either communism or nationalism in the effort to legitimate party rule.

Of course, nationalism and communism have presented themselves in myriad ways and have developed over time, with enormous scholarly literatures underpinning each. This article relies on the Oxford Handbook of Political Ideologies (Freeden et al. 2013) to lend content to the terms 'communism' and 'nationalism' and to constituent terms that can be coded in the quantitative text analysis and examined in the qualitative analysis performed below. The entries in the Handbook have been explicitly designed to distil the main features of the respective ideologies.

Archie Brown (2013: 371) puts forward the distinctive characteristics of 'communist ideology in power'. He argues that besides the aforementioned vanguard position of the party, communist regimes in power secondly proffered democratic centralism within the party even if it was in practice often more about power politics and strategic co-optation. Thirdly, state ownership of the means of production is essential to the communist idea. Fourthly and closely interlinked to the third characteristic is the centrally planned economy that was perceived as being more just and more efficient than the market economy (Brown 2009: 110-114, 2013: 371-377). With these four common features of communism (party as vanguard, democratic centralism, state ownership, centrally planned economy) in mind, the terms listed in Figure 1 under 'communism' are understood as adjacent to the core concept.

In a similar vein, Andrew Vincent (2013: 463) has tried to synthesize the 'regulative themes of nationalist ideologies'. He puts forward six features that can be seen as adjacent to the core of nationalism. Firstly, nationalism is based on an understanding that humanity can be fragmented into distinct groups with distinct ethnicities; secondly, a strong sense of common identity is linked to it; thirdly, a nation is often identified with territorial boundaries; fourthly, it is often associated with sovereignty; fifthly, a nation invokes strong feelings of a common culture in which universal values are embedded; sixthly, nations are self-determining entities that seek their own prosperity and should aim to guarantee the secure development and prosperity of their citizens (Vincent 2013: 463-470). The terms in Figure 1 were derived with these six features in mind (ethnicity, identity, territory, sovereignty, culture and prosperity) and are taken as adjacent to the core of nationalism.

\section{Empirical analysis: communist legitimation in a changing world}

The main idea behind the text analysis is to detect changes in the semantics of concepts over time. ${ }^{3}$ In sum, the freeze-frame strategy would be to keep initial semantics intact without significant shifts. The adaptive strategy, in contrast, would be responsive to external changes and would incorporate semantic shifts. Like a seismograph for societal change, the adaptive strategy works best if it is able to react by shifting meaning before the damage is done.

For text analysis of North Korea, all available New Year's messages from 1981 to 2012 in English using official North Korean translations were collected and analysed. These messages can be understood as yearly programmatic texts that 


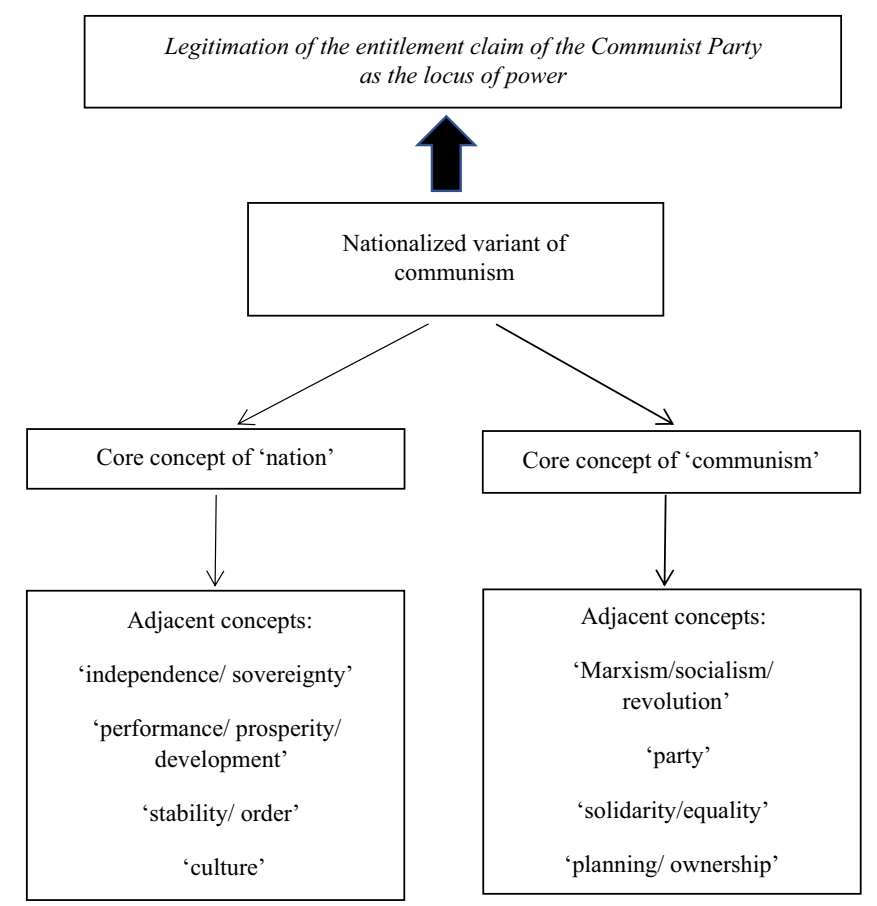

Figure 1. Key Terms for Nationalism and Communism

summarize past achievements and future aspirations. They are jointly edited by the main official organs and can be seen as a consensual text of the forces within the ruling bloc. In this light, they are comparable to the documents the Chinese Communist Party (CCP) publishes after the end of its regular party congresses held every five years. The CCP reports under study rely on official CCP Englishlanguage translations and span from 1977 to 2012.

Relevant documents were digitized and preprocessed to delete punctuation and stopgap words. The word count matrix of the text corpora was then analysed for frequency rates and for keywords in context. The main idea behind this approach is to measure salience and association: the more often a term co-occurs in the direct neighbourhood $^{4}$ of identified key terms the more influential it is to that idea or concept. We identify words that appear constantly in the direct neighbourhood of this semantic conglomerate of 'nation' and 'communism' and interpret the changing patterns over time. ${ }^{5}$

The analysis illustrates the logics of both approaches to legitimation; that is, the freeze-frame and adaptability strategies. North Korea and Cuba were chosen as typical cases of relatively unreformed communism in the post-Cold War period to probe attempts at a freeze-frame strategy. China and Vietnam were chosen as cases of reformed communist systems that attempted to introduce more robustly flexibility and adaptability into their legitimating formulas. It must be stressed that the freeze-frame and adaptability strategies to legitimation are Weberian ideal types. It is thus not the case that in their efforts to be adaptable China and Vietnam 
jettisoned everything relating to communism, nor is it the case that North Korea and Cuba employed completely static legitimation strategies over time. Rather, the pairs of cases can be seen as existing on a spectrum closer to one ideal-typical strategy or the other.

Text analysis is only performed for China and North Korea to illustrate the ideal type of each approach to legitimation. Space constraints as well as availability of comparable English-language texts over time able to be digitized preclude additional text analysis of Vietnam and Cuba, but qualitative analysis of each case reveals similar approaches to legitimation as China and North Korea, respectively. The time frame of our text analysis is focused on the developments from the 1980s until 2012. However, the case narratives provide more background information on the historical setting and the conclusion discusses implications for today.

\section{Towards the ideal type of freeze-framed legitimation: North Korea and Cuba}

North Korea and Cuba can be seen as prime examples of regimes that attempted to freeze-frame legitimating concepts. By so doing, they endeavoured to provide stable reference points to facilitate an internalized, unchallenged and dogmatic interpretation of a legitimating ideology. Communism Cuban and North Korean style attempted to offer an orthodox route through a semantic map of essentially contested concepts. Nation, independence and sovereignty, as well as communism, socialism, solidarity and equality are all concepts whose meaning can change with the spatiotemporal context. However, Cuba and North Korea worked to freeze their meaning and produce stable expectations - both within the elite and vis-à-vis its population. Only when this strategy became difficult to sustain in the 1990s did they attempt gradual adaptive changes; however, their autonomy over the adaptation process can be questioned and the adaptive velocity was debilitatingly slow. In terms of timing and sequencing, they learned to learn too late, such that their adaptations were 'life sustaining' rather than 'capacity enhancing' (see Deutsch 1973: 145-149).

If one tries to identify the core of North Korea's Juche ideology, it must be an almost obsessive focus on the country's independence (Armstrong 2013; Cumings 1997: 40-41; Oh and Hassig 2000: 17). It is a dogma of self-reliance and autonomy. The traumatic experience of Japanese colonial rule until the end of World War II, the violence of the Korean War, and developments during the Cold War can all help explain this strong desire. Economic self-reliance has been depicted as the foundation for political independence while military power is upheld as a guarantor of national sovereignty.

Text analysis helps to illustrate legitimation efforts in North Korea over time. Figure 2 plots the absolute frequency of nationalist and communist terms against each other over time. ${ }^{6}$ One can see an oscillation of the respective usage of nationalist and communist discourses. While most of the time they parallel each other, we see a peak of nationalistic claims in the 1990s that can be explained by the collapse of the Soviet Union. In times of crisis, reference to the nation seemed to be safer than relying on the fading fortunes of international communism. 


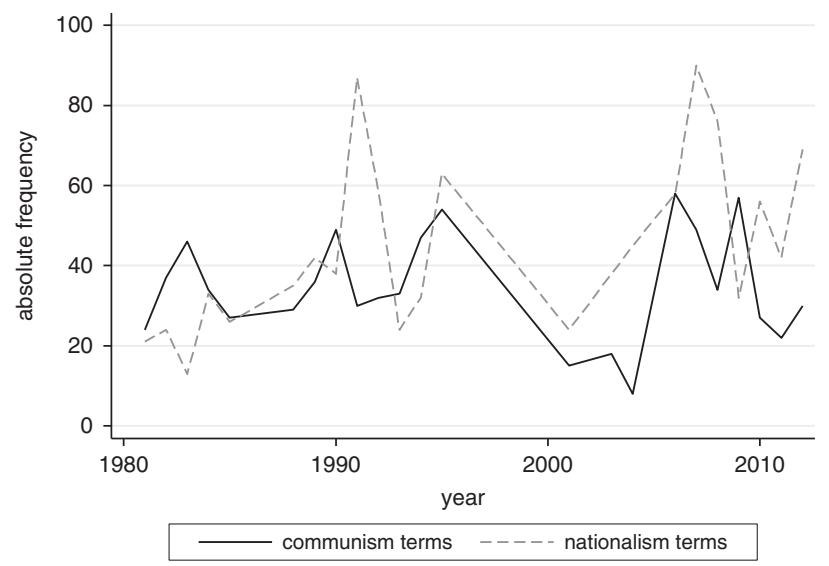

Figure 2. Frequency of Terms: Communism and Nationalism in North Korea Source: Own illustration.

After the 'mourning period' (1994-7) in which Kim Jong Il gradually took over power after his father's death, one can observe a remarkable decrease in the frequency of both nationalist and communist terms. This period encompasses economic hardship in North Korea and a devastating famine (Haggard and Noland 2007). During this period, the regime remained largely silent on both legitimacy claims. The discourse was characterized by slogans about endurance. The mid2000s saw a sharp increase in the usage of nationalist terms, which dominate until today, while reference to communism has declined. In this light, we can see an adaptation that travels a small distance with late timing and uneven velocity.

In a second step, a keyword in context analysis was conducted. We compare the 10 most frequent terms at the beginning and the end of our observation period (1981 and 2012) that co-occur in the direct neighbourhood of communist key terms. ${ }^{7}$ This allows one to identify the most frequent and therefore most salient attributes that the joint editorial has attached to communism. As Table 1 summarizes, the most frequent terms in 1981 were: 'construct', 'peopl', 'economi', 'work', 'countri', 'nation' and 'parti'. In 2012, the most frequent terms surrounding communist terms were: 'juch', 'kim', 'caus', 'jong' and 'countri'.

The semantic picture that emerges when comparing the 10 most important terms is one of comparatively strong semantic freezing. One notable difference is the tendency to personalize communism in 2012 as 'kim' and 'jong' are the second and fourth most frequent terms surrounding communist keywords, respectively. Communism is coupled more tightly to the person of the ruler. Moreover, we observe a gradual but steady decline of the usage of 'construct' over the years. While being in 1981 by far the most frequent term, its usage in relation to communism has dropped considerably. Besides these two tendencies, downplaying 'construct' and emphasizing the person of the ruler, the keywords in communist context remain by and large unchanged and resemble orthodox 'communistspeak'. Terms like 'countri', 'nation', 'caus', 'life', 'great', 'will', 'way' are also to a large extent empty signifiers that do not carry distinguishable and significant meaning. The exception is the most salient term in the neighbourhood of 
Table 1. Most Frequent Words Surrounding Communist Terms in North Korea

\begin{tabular}{ll}
\hline In 1981 & In 2012 \\
\hline 'construct' & 'juch' \\
'peopl' & 'kim' \\
'economi' & 'caus' \\
'work' & 'jong' \\
'countri' & 'countri' \\
'nation' & 'achiev' \\
'parti' & 'life' \\
'caus' & 'great' \\
'build' & 'will' \\
'cultur' & 'way' \\
\hline
\end{tabular}

Source: Own source.

communist key terms in 2012, namely 'juch'. This is striking. As the discussion above illustrates, however, this is not old wine in new bottles because in this case even the bottles are old. Rather than adapting, North Korea retreated into known and semantically settled concepts. In this light, we cautiously conclude that North Korea's semantics on communism have not altered in major ways. The semantic distance that the ideology travelled in the last decades is relatively small.

We argue that the North Korean regime generally uses the same terms in conjunction with the communist cause. It is a constant repetition of known content that aims to install a relatively frozen and unchanging semantic map in the minds of North Korean citizens. The same holds true using similar analysis with terms that appear constantly over time in the direct neighbourhood of nationalist legitimizing discourse. Table 2 lists the most frequent terms in the direct neighbourhood of nationalist keywords. If we compare the language that has been used in direct connection to nationalism, we do not observe major semantic shifts. Analogously to the communist discourse, the nationalist discourse has remained even more consistent. The most frequent terms remain references to reunification and the building/establishing/achieving of a strong economy in the country.

Both nationalist and communist discourses have been by and large frozen in time. With regard to the four parameters that we introduced above, the observed experimentations with ideological adaptations in recent years have been: (1) born

Table 2. Most Frequent Words Surrounding Nationalist Terms in North Korea

\begin{tabular}{ll}
\hline In 1981 & In 2012 \\
\hline 'reunif' & 'reunif' \\
'product' & 'build' \\
'economi' & 'achiev' \\
'independ' & 'kim' \\
'revolut' & 'nation' \\
'establish' & 'new' \\
'technic' & 'countri' \\
'countri' & 'sector' \\
'socialist' & 'thrive' \\
'parti' & 'economi' \\
\hline
\end{tabular}

Source: Own source. 
out of a position of weakness and low autonomy over semantic changes; they were reactive rather than proactive. Furthermore, the semantic changes have been: (2) late in timing, (3) at a slow pace and overall (4) relatively limited in scope.

There are striking parallels between North Korea and Cuba as the Cold War wound down. Both states had charismatic leaders: Kim Il Sung in North Korea and Fidel Castro in Cuba. Neither communist party was militarily dependent upon the Soviet Union to maintain power (Dimitrov 2013), but both were reliant on economic exchange with other communist states for their prosperity. Similar to North Korea, the Cuban economy began to experience serious problems in the mid-1980s that were then compounded by the ultimate disappearance of the Soviet economy (Brundenius 2009). Like North Korea, Cuba also followed the strategy of freezing the meanings of its legitimation efforts amidst the changing global context, only taking measures to adjust its legitimation after conditions had deteriorated to such an extent that the party felt existentially insecure.

Since taking power in 1959 the Communist Party of Cuba (CPC) has always suffused its ideology with nationalism and patriotic pride, but prior to the 1990s this was subsumed to an internationalist version of communism and MarxismLeninism. Cuba attempted to support revolutions abroad and promoted goals of international communism by sending troops and/or workers with specialized expertise to aid socialist construction in other countries (Westad 2005). After the fall of the Soviet Union, however, the content of Cuba's ideology emphasized themes associated with nationalism and sovereignty and downplayed global Marxism-Leninism (Rabkin 1992). Themes of nationalism and sovereignty could be found in the Cuban communist tradition previously, but they gained newfound prominence from the 1990s onwards as the party embarked on a campaign to reorient its ideological education strategy (Rojas 2007).

The 1986 Main Report of the Third Congress of the Communist Party is instructive because it came on the eve of the Soviet collapse. Given that the CPC did not foresee changes to global communism in the late 1980s and early 1990s, this report can be seen as the party's consensual statement regarding its communist revolution during a time when it perceived that global communism was more resilient than it ultimately turned out to be. The document discusses its 'long-range economic, scientific and technological cooperation development program between Cuba and the Soviet Union up to the year 2000' and its 'broad coordination of long-term plans with the socialist countries' up to the year 2000 (Communist Party of Cuba 1986: 108, 47). Analysis of international developments in the report make clear that the CPC not only failed to anticipate the rapid decline of communism, but fully expected the Soviet Union, with its 'enormous economic potential, its unquestionable military might, and its loyalty to the principles of MarxismLeninism and proletarian internationalism', to continue to lead the cause of global communism indefinitely (Communist Party of Cuba 1986: 107).

Far from the economic experimentation and flexibility endorsed by parties in Vietnam and China during this period, the CPC stuck to an orthodox line in 1986. The most important ideological and political goal of the party, according to the 1986 report, remained the building of socialism while avoiding the 'slightest indication of bourgeois attitudes and corruption' and thwarting the undisciplined and selfish 'petty bourgeois spirit' (Communist Party of Cuba 1986: 88). The report 
was frank about some of the shortcomings of Cuba's economy in the previous five years, but nonetheless looked forward to the period of 1986 to 1990 as one in which it saw a $5 \%$ annual growth rate as 'feasible thanks to ... economic relations with the socialist countries' (Communist Party of Cuba 1986: 39).

With hindsight, it is obvious that these targets were not met. Soviet reforms in the late 1980s 'were greeted in Havana with mounting disbelief and dismay, and eventually with open repudiation and rejection' and Cuba embarked on a policy of 'rectification' that reaffirmed the ideological principles that had animated the revolution since its inception (Perez 1995: 381-387). As Castro put it in 1989, 'the first trench in the defense of our country are the ideas, its ideology' (quoted in Rabkin 1992: 28).

In August 1990, the party began a process of forced adaptation known as the 'Special Period in Time of Peace'. The 1991 Party Congress endorsed a degree of political pluralism as it called for an increase in public debate and consultation (Cole 2002). Despite this ostensible opening, party control of the public sphere remained firm (Aguirre 2002), and the government sought to reinvigorate its legitimation on patriotic and sovereign nationalist grounds. The emphasis on nationalism resulted in a renewed focus on reconstructed national myths and a 'battle of ideas' that aimed to instil patriotism and safeguard sovereignty (Rojas 2007).

The attempt to emphasize sovereignty and independence over MarxismLeninism and proletarian internationalism came relatively late and still did not allow for significant policy flexibility or ideological pluralism. The party sought to de-contest the meanings of sovereignty and independence such that they were synonymous with rule by the CPC. The prescription was more vigilance and patriotism against US aggression over communist solidarity. While Cuba attempted an adaptation, it was not to change the content of what it meant to be communist but rather a reshuffling of emphasis within its constellation of legitimating values.

\section{Towards the ideal type of adaptive legitimation: China and Vietnam}

The communist parties of China and Vietnam initiated significant economic reforms beginning in the late 1970s and mid-1980s, respectively. The crux of the reforms in each country was to lessen the role of the party-state in the economy and to provide more space for market mechanisms to operate. On the eve of reforms, China was emerging from the chaos and fervour of the Cultural Revolution while Vietnam was experiencing acute economic challenges and attempting post-war reunification. In China reforms that gave more priority to market mechanisms became possible after the death of Mao Zedong in 1976 and the solidification of Deng Xiaoping's rule at the top of the leadership hierarchy from 1978. The death in 1986 of Vietnam's Le Duan, who had occupied the top party post for over 25 years and who held orthodox Marxist views (see Vu 2017), allowed the party more latitude to embark on reforms. In each case market-oriented reforms contributed to decades of economic growth and revitalization, although both governments retain significant control over important sectors and enterprises (Malesky and London 2014). 
Initial reforms in each case were born of the endogenous recognition that the party would need to deliver increased prosperity to the population in order to maintain power and legitimacy. The tension, however, was that the proffered reforms in each case strayed from conservative interpretations of Marxist-Leninist principles insofar as they called for the party-state to scale back some elements of central control. In China this was justified by Deng's arguments that markets and central control were methods used by both capitalist and communist systems, not ends in themselves. Vietnam, in the midst of serious economic problems, was 'by the late 1980s ... torn between clinging to orthodox ideology and moving to a more open, less centralized economy' (Turnbull 1999: 308). The Sixth Party Congress in 1986 saw expanded scope for discussions and debates about how to respond to the country's dire economic realities and ultimately a programme of doi moi ('revitalization' or 'renovation') was formulated to develop 'a market economy with a socialist orientation' (Thayer 2010: 427). While implementation of reforms launched in 1986 partially languished until at least 1989 due to conservative resistance, the scope of ideologically acceptable thinking was nonetheless significantly expanded in the interim (Elliot 2012: 51-57).

In China, the party studied the collapse of the Soviet Union extensively to distil lessons from the USSR's downfall. The adaptation velocity - that is, how fast the regime learned to learn - has been high. One of the many lessons learned was that a 'dogmatic ideology' was harmful to the party's resilience (Shambaugh 2008: 4). A rigid, ossified ideology is thus seen by the CCP as a liability, but it cannot disregard Marxism-Leninism entirely because too much of its legacy and historical legitimacy is bound up with it. Since the ascension of Deng the CCP has chosen to 'finesse and adapt' the ideology (Holbig 2013; Shambaugh 2008: 105).

The party's ideology adapted with changing social conditions but has remained an indispensable pillar of the CCP's rule. The CCP has attempted to provide flexible ideological constructs that can accommodate the changing needs of China and the party. Concepts like Jiang Zemin's 'Three Represents' helped justify the inclusion of entrepreneurs into the party while Hu Jintao's 'Socialist Harmonious Society' called for more regionally balanced economic growth (Brown 2012). Along with these flexible concepts, it has been widely noted that the CCP has downplayed Marxism-Leninism and emphasized nationalistic sentiment to help legitimate its rule. The infusion of nationalism is thought to help identify the CCP with China's increasing power and muscular foreign policy, although nationalist discourses can sometimes be critical of the party if, for example, it is perceived by nationalist commentators as not standing up sufficiently to Western powers (Seckington 2005).

The party's documents adopted at the Party Congress, held every five years, reflect these adaptable currents. Figure 3 shows the absolute frequency of the usage of nationalist and communist terms over the years. The trend is obvious and consistent with qualitative case knowledge. Communism - be it in its socialist, Marxist or revolutionary sense - became downplayed in China. The decrease in the communist discourse is paralleled with an increase in nationalist terms. Reference to communism was nearly three times more common than nationalism in 1977 but only half as frequent in 2012. In contrast to the North Korean case, the Chinese case displays a clear-cut picture: nationalism rises, communism declines - and this 


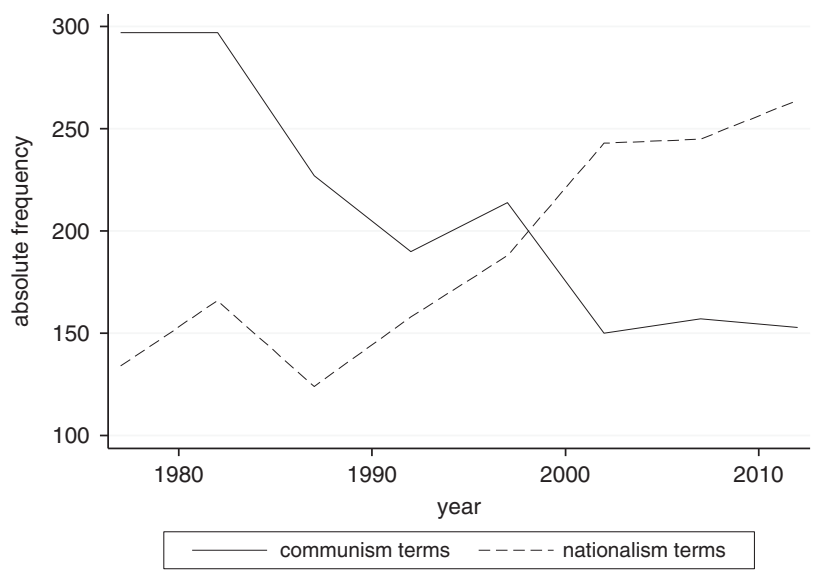

Figure 3. Frequency of Terms: Communism and Nationalism in China Source: Own illustration.

for the last 30 years. In China the relationship between the two core concepts of the ideological 'macroscopic structural arrangement' (Freeden 1994: 141) of national communism has been almost completely reversed. It has adapted to changing circumstances and has fundamentally changed the composition of its ideological discourse.

Using the same procedures for measuring co-occurrence as in the North Korean case, Table 3 shows the most frequent terms associated with Chinese communism in $1977 .^{8}$ In the 1970 s, communism in China was characterized by revolutionary appeal. Indeed, 'revolution' was the third most salient term. Taken together with 'socialist', 'parti', 'line' and the reference to 'chairman' 'mao', we interpret these contextual words semantically as revolutionary zeal and fervour. The picture is complemented by 'great' and 'struggle', which refer to an activist language.

The most frequent terms in 2012 stand in stark contrast. While we have seen a steady decline of communist wording over the years in absolute terms, it is interesting to note that communism today is associated closely with the nation: 'china' is the most salient term in connection with communism. A nationalization

Table 3. Most Frequent Words Surrounding Communist Terms in China

\begin{tabular}{ll}
\hline In 1977 & In 2012 \\
\hline 'socialist' & 'china' \\
'parti' & 'develop' \\
'revolut' & 'system' \\
'mao' & 'parti' \\
'chairman' & 'law' \\
'line' & 'modern' \\
'peopl' & 'improv' \\
'countri' & 'cultur' \\
'great' & 'polit' \\
'struggl' & 'socialist' \\
\hline
\end{tabular}

Source: Own source. 
of communism has taken place. Moreover, the analysis of keywords in context shows that the 2012 discourse aims at modifying communism. Terms surrounding communism today are 'develop', 'improv', but also the more technocratic 'system' and 'modern'. This pattern signifies a need for reforming old-style communism. What was perhaps the most surprising term in the neighbourhood of communism today was the fifth-largest: 'law'. Communism and law had no connection in the 1970s at all but in 2012 were used with a relative frequency of $10 \%$. This means that whenever a communist term occurs in the 2012 party line, in 10\% of the cases 'law' is associated with it. This shows that communism of the 1970s has changed considerably. Today, party ideologues redefine what communism means in the 21st century. The picture is complemented by semantic shifts with regard to cultural and political interpretations of communism - and away from dominantly ideological and economic understandings.

When it comes to the interpretation of the most frequent terms surrounding nationalism in China, a similar change can be detected. China has moved from a revolutionary language in the 1970s in which nationalist keywords were surrounded by the 'great' 'proletarian' revolution and by 'socialist' organs like the 'armi', the 'parti', the 'congress' and 'committe'. The terms that define Chinese nationalism in the 21st century differ. More societal aspects are emphasized. While there is some overlap with the Chinese people, it is surprising to see that 'respect', 'cultur', and 'modern' are among the most frequent terms in 2012 that define the meaning of nationalism. There is a remarkable shift in the nationalist discourse. Table 4 displays this semantic shift.

While North Korea tended towards the freeze-frame ideal type, the Chinese case is more reflective of a flexible adaptation strategy. When comparing the 10 most frequent terms at the beginning and at the end of our observation period, the terms change drastically. But it is not only the frequency of these terms, but also the semantic meanings that they carry. While the former language was one of revolutionary passion, today's language aims at correcting, modifying and modernizing communism.

With regard to the four parameters of ideological analysis introduced previously (autonomy over the process, timing, velocity and distance), the Chinese government has actively coped with the changing national and international situation. The CCP did so early and learned to learn very quickly. In this sense, the adaptations made by the CCP have been more creative and enabling rather than the

Table 4. Most Frequent Words Surrounding Nationalist Terms in China

\begin{tabular}{lc}
\hline In 1977 & In 2012 \\
\hline 'peopl' & 'chines' \\
'great' & 'develop' \\
'revolut' & 'peopl' \\
'proletarian' & 'china' \\
'parti' & 'promot' \\
'congress' & 'build' \\
'armi' & 'societi' \\
'socialist' & 'respect' \\
'whole' & 'culture' \\
'committe' & 'moder' \\
\hline
\end{tabular}

Source: Own source. 
'life-sustaining' reactive adaptations made by Cuba and North Korea. China retained relative autonomy over the adaptation process and travelled so far that the ratio between communism and nationalism reversed.

Turning our attention to Vietnam, changes in the party's documents adopted at the National Congress, held every five years, reflect the Vietnam Communist Party's (VCP) ideological adaptability. The Fifth Party Congress, held in 1982, took place amid serious economic troubles and ongoing war with Cambodia. The Central Committee report to the VCP called for an application of MarxismLeninism to the conditions of Vietnam (Vietnam Communist Party 1982: 11) while asserting that 'collective mastery is the greatest, the finest and loftiest feature of man' (Vietnam Communist Party 1982: 27). Patriotism was synonymous with socialism (Vietnam Communist Party 1982: 28), while cooperation with the Soviet Union, which was 'advancing vigorously' as the 'pillar' of the worldwide communist movement, was a 'manifestation of revolutionary sentiments' (Vietnam Communist Party 1982: 42-46).

By 1986 Vietnam's economy was in worse shape and, as mentioned above, the death of Le Duan that year facilitated a wider scope for debate within the party. The 1986 Sixth VCP Congress resolution and political report revealed more adaptability in the face of changing circumstances. The resolution admitted that plans for the previous five years had not been met (Vietnam Communist Party 1986: 2), and acknowledged serious shortcomings in its ideological perspectives (Vietnam Communist Party 1986: 19). The party needed to remind itself of 'the idea of regarding the people as the base' and had to 'first of all renovate its perceptions and thinking' in order to stabilize the economy and improve the living conditions of the population (Vietnam Communist Party 1986: 20). Although the report still lauded the Soviet Union, it also recognized new scientific and technological advances in the world (Vietnam Communist Party 1986) and called for Vietnam to 'combine the strength of the nation with the strength of the era' (Vietnam Communist Party 1986: 8).

The initial stages of the disintegration of the Soviet Union were met with confusion and sharp debate within the party's elite (Elliot 2012: 59-85; see also Vu 2017: 252-258). They vigorously debated how the party ought to legitimize its rule. In open letters, public speeches, party meetings, essays and manifestos, a group of communist intellectuals and leaders 'criticized the continued salience of ideology and the party's closed undemocratic decision-making process' (Thayer 2010: 429). Conservatives who opposed further political liberalization responded to these challenges and seemed to overcome their initial paralysis in reacting to developments elsewhere in the communist world.

The 1991 Party Congress elected a leadership that was staunchly Leninist in its political outlook but technocratic and market-oriented in its economic outlook, which suggests that the party was seeking to augment the foundations of its performance legitimation (see London 2009: 387-388). After the fall of the Soviet Union, the more flexible legitimation formulas previously codified by the VCP in the mid- to late 1980s meant that, despite initial confusion and disarray in response to the collapse, the VCP had the necessary material to adapt its legitimation swiftly to new realities. The 1991 Congress legitimized the idea of a socialist market economy (Pike 1992), which would have been more difficult to do without the 
foundation laid by the 1986 Congress. The difficulties in other socialist states were attributed in 1991 not to any shortcomings of socialism itself but rather to subversion by 'international reactionary forces' (Vietnam Communist Party 1991: 14). Yet at the same time the document distanced itself from wholly embracing international communism by stressing that the socialist goals for Vietnam were those chosen by Ho Chi Minh (Vietnam Communist Party 1991: 17), thus highlighting the nationalistic credentials of the VCP over universalist aspirations. The Congress affirmed Marxism-Leninism and rejected multiparty democracy but noted that 'what is new in the documents of this party congress is that together with Marxism-Leninism, the party upholds Ho Chi Minh's thought' (Vietnam Communist Party 1991: 22). The foundations for this move had been laid previously as the promotion of 'Ho Chi Minh Thought' starting in the mid-1980s was an attempt to lend the contemporary party some of 'Uncle Ho's' charismatic legitimacy (Thayer 2010: 427).

These developments allowed for a 'creative' application of socialist principles to the 'specific conditions' of Vietnam. The VCP directly acknowledged its strategy of ideological adaptability at the Seventh Congress, noting not only its creative application of socialist principles, but also admitting that 'of course, our current concepts - though they are correct today - will be supplemented and developed tomorrow, together with the development of reality, thought, and theory' (Vietnam Communist Party 1991: 17).

By the 1996 Eighth Congress, the VCP looked back on nearly a decade of reform and stressed that it was not abandoning socialism, but that its policy of doi moi is a combination of persistence in revolutionary principles and strategy, on the one hand, with tactical flexibility and creativity and a quick grasp of the new on the other' (Vietnam Communist Party 1996: 26). While socialism was in a difficult period, 'mankind is still in the era of transition from capitalism to socialism' and 'national struggle and class struggle continue to unfold in diverse forms' (Vietnam Communist Party 1996: 33). While the velocity, the timing and the ideological distance may lag behind the Chinese model, the VCP has clearly displayed a proactive and adaptable approach to legitimation. On balance, this has enhanced the autonomous capacities for further adaptation instead of being merely life sustaining.

\section{Conclusion}

This article has analysed four communist regimes and argued that they took one of two paths to legitimate themselves in a post-communist world. Our aim was not to provide a full explanation of why these regimes have weathered times of ideological crises, but rather how they did so. While all four governments under examination were characterized by some version of national communism, their emphasis on constituent concepts changed over time. The cases under study can be placed on the continuum of different legitimation strategies that range from the ideal types of freeze-framing and adaptation.

We introduced four parameters that help to distinguish ideological changes empirically (autonomy over semantic changes, timing, velocity and the distance that an ideology travels) and applied them to the remaining communist regimes. North Korea made minimal adaptations and is a case closer to the pole of freezing 
semantics, while Cuba was a cautious, but late mover. Neither acted out of a position of strength and their adaptations can be described as rather reactive to the demise of communism. In contrast, China and Vietnam proactively emphasized nationalism, development, national power and ideological flexibility, and downplayed themes associated with a more rigid adherence to communism - with China being unparalleled when it comes to velocity, distance and autonomy over the adaptation process. China and Vietnam therefore had more flexible but sturdier foundations of legitimation in a world of fewer communist regimes than did North Korea and Cuba, both of which emphasized the role of the regime in safeguarding national sovereignty in a suddenly hostile world. The result in the latter two cases is a legitimation formula that has helped each party stay in power but that has been less able to incorporate dynamism and flexibility.

While our aim was not to determine causality, our working hypothesis to explain divergent legitimation trajectories revolves around the longevity of founding leaders in each case. Communist political systems facilitate the emergence of personalist leaders due to the lack of institutionalized checks and balances (McAdams 2017). Each of the four cases here featured charismatic and influential founding figures. In the two cases closer to the freeze-frame pole, those figures lived past the Soviet collapse, with Kim Il Sung dying in 1994 and Fidel Castro in 2016. The presence of the founding figures of each communist movement made it more difficult for the system to distance itself from his ideas until late in the game, thus impacting in particular the timing and distance of ideological changes. In the two cases closer to the adaptation pole, charismatic founding leaders were long gone by the time the Soviet Union collapsed, which helped ease constraints on ideological adaptation. In China, Mao's death in 1976 ultimately paved the way for a degree of liberalization. In Vietnam, Ho Chi Minh died in 1969 and while Le Duan was the dominant political figure after Ho's death, he did not have the latter's charisma. In any case he also died in 1986, which helped the VCP adapt afterwards.

Our analysis ends in 2012, but as of this writing, each communist party remains in power. Vietnam and China have continued to emphasize the nationalist elements of national communism. However, China has seen the re-emergence of personality cult dynamics in the form of 'Xi Jinping Thought'. The 'Core Socialist Values' that accompany 'Xi Jinping Thought' stress themes similar to the core of nationalism, so we are likely to see an intensification of China's nationalist-leaning national communism. In Cuba the death of Fidel has allowed his brother Raul to de-emphasize international communism and instead focus on reform and domestic performance. Time will tell how far the Cuban party will travel from Fidel's ideas, but the leadership turnover has allowed a degree of change. In North Korea, dynastic rule continues under Kim Jong Un, who has emphasized economic well-being and limited marketization while retaining the nationalist core of North Korean ideology.

Finally, this article not only has relevance for understanding the four communist regimes under examination, but it also bears on broader debates in the comparative study of authoritarianism. It foregrounds ideology and legitimation and thereby adds to prevailing explanations in the literature on authoritarianism that emphasize institutions and repression. Research on autocratic legitimation is burgeoning in case studies (Dukalskis and Hooker 2011; Gill 2011; Holbig 2013) and comparative research designs (Grauvogel and von Soest 2014; Kailitz and 
Stockemer 2017). In conjunction with the rich insights from the renaissance in studying political ideologies in general (Freeden 2007; Maynard and Mildenberger 2018) this article contributes to a newly vibrant field by developing a theoretical framework that can be applied beyond communist-style states.

Supplementary material. To view supplementary material for this article, please visit https:/doi.org/ 10.1017/gov.2018.40.

Acknowledgements. The authors would like to thank Orla Ni Cheallachain (UCD), Jirka Lewandowski (Berlin Social Science Centre, WZB) and Francois-Xavier Lefebure (UCD) for excellent research assistance. We acknowledge with gratitude financial support for research and/or dissemination from the UCD College of Human Sciences Research Fund, the School of Politics \& International Relations Research Committee, the German Research Network 'External Democracy Promotion' of the Leibniz Association, and the WZB.

\section{Notes}

1 Laos is excluded from this analysis for reasons of space and data availability.

2 Originally, Freeden (1996) introduces a tripartite distinction between core, adjacent and peripheral elements. In the following, we only make use of the broader distinction between an ideological core and adjacent elements.

3 Political scientists have adopted quantitative text analysis with vigour (see Grimmer and Stewart 2013; Roberts et al. 2014). While recognizing that there are more complex methods available to analyse large text corpora, we rely on a relatively simple supervised frequency count and keywords-in-context approach as it is suitable to our small corpora and deductive theoretical framework.

4 In line with most studies that use this approach, we have set the direct neighbourhood to three words before and after the key words.

5 In line with our theoretical argument and following the ideological essence of communism and nationalism identified by Brown (2013) and Vincent (2013) (see Figure 1), the key terms for communism are Marxism, socialism, party, solidarity, equality, planning and ownership. The key terms for nationalism are independence, sovereignty, performance, prosperity, development, stability, order and culture.

6 The word length of the joint editorials is comparable.

7 In the online appendix to this study, we present the 'career' of the most frequent keywords in context. This shows the development of the most frequent terms surrounding nationalism and communism in North Korea over time.

8 In the online appendix, we present the 'career' of the most frequent keywords in context. This shows the development of the most frequent terms surrounding nationalism and communism in China.

\section{References}

Aguirre BE (2002) Social Control in Cuba. Latin American Politics and Society 44(2), 67-98.

Almond GA and Powell GB (1978) Comparative Politics: System, Process, and Policy, 2nd edn. Boston, MA: Little, Brown.

Armstrong CK (2013) Ideological Introversion and Regime Survival: North Korea's 'Our-Style Socialism'. In Dimitrov MK (ed.), Why Communism Did Not Collapse: Understanding Authoritarian Regime Resilience in Asia and Europe. Cambridge: Cambridge University Press, pp. 99-119.

Barker R (2001) Legitimating Identities: The Self-Presentations of Rulers and Subjects. Cambridge: Cambridge University Press.

Beetham D (1991) The Legitimation of Power. Basingstoke: Palgrave Macmillan.

Brown A (2009) The Rise and Fall of Communism. London: HarperCollins.

Brown A (2013) Communism. In Freeden M, Sargent LT and Stears M (eds), The Oxford Handbook of Political Ideologies. Oxford: Oxford University Press, pp. 364-384.

Brown K (2012) The Communist Party of China and Ideology. China: An International Journal 10(2), 52-68.

Brundenius C (2009) Revolutionary Cuba at 50: Growth with Equity Revisited. Latin American Perspectives 36(2), 31-48. 
Chwe MSY (1999) Structure and Strategy in Collective Action. American Journal of Sociology 105(1), 128-156.

Cole K (2002) Cuba: The Process of Socialist Development. Latin American Perspectives 29(3), 40-56.

Communist Party of Cuba (1986) Main Report, Third Congress of the Communist Party of Cuba. Havana: Editora Politica.

Cumings B (1997) Korea's Place in the Sun: A Modern History. New York: Norton.

Dahl RA (1971) Polyarchy: Participation and Opposition. New Haven: Yale University Press.

Deutsch KW (1973) Politische Kybernetik: Modelle und Perspektiven. Freiburg: Rombach Verlag.

Dimitrov MK (2013) Why Communism Did Not Collapse: Understanding Authoritarian Regime Resilience in Asia and Europe. Cambridge: Cambridge University Press.

Dukalskis A (2017) The Authoritarian Public Sphere: Legitimation and Autocratic Power in North Korea, Burma, and China. New York: Routledge.

Dukalskis A and Gerschewski J (2017) What Autocracies Say (and What Citizens Hear): Proposing Four Mechanisms of Autocratic Legitimation. Contemporary Politics 23(3), 251-268.

Dukalskis A and Hooker Z (2011) Legitimating Totalitarianism: Melodrama and Mass Politics in North Korean Film. Communist and Post-Communist Studies 44(1), 53-62.

Elliot DWP (2012) Changing Worlds: Vietnam's Transition from Cold War to Globalization. Oxford: Oxford University Press.

Freeden M (1994) Political Concepts and Ideological Morphology. Journal of Political Philosophy 2(2), $140-164$.

Freeden M (1996) Ideologies and Political Theory: A Conceptual Approach. Oxford: Oxford University Press.

Freeden M (2007) The Meaning of Ideology: Cross-Disciplinary Perspectives. London: Routledge.

Freeden M, Sargent LT and Stears M (eds) (2013) Oxford Handbook of Political Ideologies. Oxford: Oxford University Press.

Gallie WB (1956) Essentially Contested Concepts. Proceedings of the Aristotelian Society 56, 167-198.

Gerring J (1997) Ideology: A Definitional Analysis. Political Research Quarterly 50(4), 957-994.

Gerschewski J (2013) The Three Pillars of Stability: Legitimation, Repression, and Co-optation in Autocratic Regimes. Democratization 20(1), 13-38.

Gerschewski J (2018) Legitimacy in Autocracies: Oxymoron or Essential Feature? Perspectives on Politics 16(3), 652-665.

Gill G (2011) Symbols and Legitimacy in Soviet Politics. Cambridge: Cambridge University Press.

Gilley B (2009) The Right to Rule: How States Win and Lose Legitimacy. Cambridge: Cambridge University Press.

Grauvogel J and von Soest C (2014) Claims to Legitimacy Count: Why Sanctions Fail to Instigate Democratisation in Authoritarian Regimes. European Journal of Political Research 53(4), 635-653.

Grimmer J and Stewart BM (2013) Text as Data: The Promise and Pitfalls of Automatic Content Analysis: Methods for Political Texts. Political Analysis 21(3), 267-297.

Haggard S and Noland M (2007) Famine in North Korea: Markets, Aid, and Reform. New York: Columbia University Press.

Holbig H (2013) Ideology after the End of Ideology: China and the Quest for Autocratic Legitimation. Democratization 20(1), 61-81.

Jost JT (2006) The End of the End of Ideology. American Psychologist 61(7), 651-670.

Kailitz S and Stockemer D (2017) Regime Legitimation, Elite Cohesion and the Durability of Autocratic Regime Types. International Political Science Review 38(3), 332-348.

King G, Pan J and Roberts ME (2013) How Censorship in China Allows Government Criticism but Silences Collective Expression. American Political Science Review 107(2), 1-18.

Knight K (2006) Transformations of the Concept of Ideology in the Twentieth Century. American Political Science Review 100(4), 619-626.

Kuran T (1997) Private Truths, Public Lies: The Social Consequences of Preference Falsification. Cambridge, MA: Harvard University Press.

Levitsky S and Way L (2010) Competitive Authoritarianism: Hybrid Regimes after the Cold War. Cambridge: Cambridge University Press.

London J (2009) Viet Nam and the Making of Market-Leninism. Pacific Review 22(3), 375-399.

Malesky E and London J (2014) The Political Economy of Development in China and Vietnam. Annual Review of Political Science 17, 395-419. 
Maynard JL and Mildenberger M (2018) Convergence and Divergence in the Study of Ideology: A Critical Review. British Journal of Political Science 48(2), 563-589.

McAdams AJ (2017) Vanguard of the Revolution: The Global Idea of the Communist Party. Princeton: Princeton University Press.

Oh K and Hassig R (2000) North Korea Through the Looking Glass. Washington, DC: Brookings Institute Press.

Parsons T (1969) Politics and Social Structure. New York: Free Press.

Perez LA (1995) Cuba: Between Reform and Revolution. Oxford: Oxford University Press.

Pike D (1992) Vietnam in 1991: The Turning Point. Asian Survey 32(1), 74-81.

Rabkin R (1992) Cuban Socialism: Ideological Responses to the Era of Socialist Crisis. Cuban Studies 22, 27-50.

Roberts ME, Stewart BM, Tingley D, Lucas C, Leder-Luis J, Gadarian SK, Albertson B and Rand DG (2014) Structural Topic Models for Open-Ended Survey Responses. American Journal of Political Science 58(4), 1064-1082.

Rojas R (2007) Ideology, Culture, and Memory: Symbolic Dilemmas of the Cuban Transition. In PerezStable M (ed.), Looking Forward: Comparative Perspectives on Cuba's Transition. Notre Dame, IN: University of Notre Dame Press, pp. 262-279.

Saxonberg S (2013) Transitions and Non-Transitions from Communism: Regime Survival in China, Cuba, North Korea and Vietnam. Cambridge: Cambridge University Press.

Schedler A (2013) The Politics of Uncertainty: Sustaining and Subverting Electoral Authoritarianism. Oxford: Oxford University Press.

Seckington I (2005) Nationalism, Ideology, and China's 'Fourth Generation' Leadership. Journal of Contemporary China 14(42), 23-33.

Shambaugh D (2008) China's Communist Party: Atrophy and Adaptation. Washington, DC: Woodrow Wilson Center Press.

Thayer CA (2010) Political Legitimacy in Vietnam: Challenge and Response. Politics and Policy 38(3), 423-444.

Turnbull CM (1999) Regionalism and Nationalism. In Tarling N (ed.), Cambridge History of Southeast Asia, Vol. 4. Cambridge: Cambridge University Press, pp. 257-317.

Vietnam Communist Party (1982) Asia \& Pacific Daily Report Supplement, 9 April 1982, Folder 05, Box 01, William Duiker Collection, Vietnam Center and Archive, Texas Tech University. www.vietnam.ttu. edu/virtualarchive/items.php?item $=0770105001$.

Vietnam Communist Party (1986) Papers on the Sixth Party Congress, 15 December 1986, Folder 06, Box 01, William Duiker Collection, Vietnam Center and Archive, Texas Tech University. www.vietnam.ttu. edu/virtualarchive/items.php?item $=0770106001$.

Vietnam Communist Party (1991) East Asia. Vietnam. Seventh CPV Congress, 26 June 1991, Folder 03, Box 05, United States Department of State Collection, Vietnam Center and Archive, Texas Tech University. www.vietnam.ttu.edu/virtualarchive/items.php? item $=4080503002$.

Vietnam Communist Party (1996) Eighth National Congress: Documents. Hanoi: Gioi Publishers.

Vincent A (2013) Nationalism. In Freeden M, Sargent LT and Stears M (eds), Oxford Handbook of Political Ideologies. Oxford: Oxford University Press, pp. 452-473.

Vu T (2017) Vietnam's Communist Revolution: The Power and Limits of Ideology. Cambridge: Cambridge University Press.

Wedeen L (1999) Ambiguities of Domination: Politics, Rhetoric, and Symbols in Contemporary Syria. Chicago: University of Chicago Press.

Westad OA (2005) The Global Cold War: Third World Interventions and the Making of Our Times. Cambridge: Cambridge University Press.

Cite this article: Dukalskis A, Gerschewski J. 2020. Adapting or Freezing? Ideological Reactions of Communist Regimes to a Post-Communist World. Government and Opposition: An International Journal of Comparative Politics 55: 511-532. doi: 10.1017/gov.2018.40 